\title{
RESILIENCE OF A CHILD FROM BROKEN-HOME FAMILY: A PHENOMENOLOGY STUDY
}

\author{
Tria Widyastuti \\ Master Program in Psychology, Universitas Gadjah Mada, INDONESIA, \\ email: tria.widyastuti@mail.ugm.ac.id
}

\begin{abstract}
A parental divorce is a stressful event for children. Several studies show that children from broken-home family have complex problems. However, some children from broken-home family are found to be able to have a good achievement and able to grow to be positive. They are able to build resilience in facing their family problems. The purpose of study was to understand how a child from broken homes achieves resilience. A phenomenology study was used in this study. Interviews and observations were used to collect data.

The subject was a 25-year-old female. The resilience framework which focuses on socio-ecological context was used to understand how the subject achieved the resilience. The parents of the subject divorced when the subject was four years old, then subject's mother remarried three times. The subject had stressors related to open conflict between her mother and father, traumatic experience through witnessing physical abuse of step father, lack of openness in communication with mother, and unsupportive friends. In this case, the resilience process began when the subject was already young adult. The subject's understanding could help her in accepting and coping the problem actively. It is supported by subject's internal characteristics including religiosity, cognitive, and social competencies which developed as the subject grown up. The openness in communication which get reciprocity from the significant other around the subject has a role in achieving resilience. Therefore, the lesson learned from this research are resilience can be achieved if the individual who exposured the stressors coped the problem actively. It is supported by both of internal and external resilience factors which include of: (1) acceptance, (2) religiosity, (3) cognitive ability, (4) social competencies, and (5) social support. In this case, mature age seemed to be an important factor in achieving resilience since it reflect maturity in those factors cited previously.
\end{abstract}

Keywords: resilience, parental divorce, family conflict, broken-home family

\section{BACKGROUND}

A parental divorce is a stressful event in children. Divorce give a great stress into the lives of adults and children (Amato\& Keith, 1990; Amato, 2014). The effect of parental divorce is diverse and complex (Cui, Fincham, \& Durtschi, 2011). Mackay (2005) revealed that after separation, most children live in the primary custody of one parent. In most cases, children live with her mother, so that the significant problem is the absence of their father. It is not just the father's presence in the home that is important, it is his presence in a child's life. Amato and Cheadle (2005) revealed that children with divorce parents tend to obtain lower 
education, have weaker ties with parents, and report more symptoms of psychological distress. Teenagers who experienced parental divorce have higher risks to develop depression symptoms, low self-esteem, aggression, alcoholic, drugs use, and criminal behavior (Rodgers \& Rose, 2002). Amato and Keith (1991) in a meta-analysis studies found that parental divorce had adverse impact on a range of domains of wellbeing including psychological adjustment, mental health, behavior, educational attainment, and quality of life. Divorce increases the risk of adjustment problems in children (Grych\& Fincham, 1990; Kelly \& Emery, 2003). Adult with divorced parents have less personal relationship commitment to their own marriages and less confidence in their own ability to maintain a happy marriage with their spouse (Whitton, Rhoades, Stanley, \& Markman, 2008)

However, not all children with divorced parents are at risk. Some children with divorced parents are found to be achievers and to be positive despite their parental divorce. Linley and Joseph (2004) mentioned that children in extreme and non-conducive environments had a positive development, despite an unpleasant experience. The success or failure of a child in dealing with parental divorce depends on the child's endurance. The endurance or capacity in dealing conflicts is called "resilience" (Chen, 2005; Masten, Best, \& Garmezy, 1990).

The use of word resilience has a long history with diverse meaning ranging from bouncing, leaping, and rebounding, to human resourcefulness, to elasticity, and resistance properties (Olsson, Jerneck, Thoren, Persson, \& O'Byrne, 2015). Resilience refers to the successful adaptation to risk and adversity (Kumpfer, 2002). More specifically, resilience is broadly defined as the process, capacity, or outcome of the successful adaptation of challenging and threatening conditions. Resilience is the positive outcome when individual faced risky condition or under pressure, and can heal from a trauma (Masten et al., 1990).

Resilience is composed of seven aspects: (1) emotional control, (2) control of impulses, (3) optimism, (4) ability to analyze problems, (5) empathy, (6) self-efficacy, and (7) attainment (Masten \& Coatsworth, 1998). Liu, Reed, and Girard (2017) found that the dynamics of the resilience process are individual interactions with social and ecological context. Olsson, Jerneck, Thoren, Persson, and O'Byrne, (2015) also said that resilience is a unifying concept within ecology and environmental studies. Resilience involves a caring family or community, an individual's ability that includes cognitive ability, regulation of emotion, positive views of self, and motivation from the environment (Masten, 2001). Bronfenbrenner and Crouter (as cited in Kumpfer, 2002) recommended the use of social ecological models or person process context models to study contextual risk relationships and protective factors, intervening processes, and individual characteristics in understanding the resilience process.

In this study, resilience will be discussed using the resilience framework of Kumpfer (2002). There is six major predictors of resilience: (1) stressor or challenge, (2) environmental context, (3) person-environment interactional process, (4) internal self-characteristics, (5) resilience processes, and (6) positive outcomes. The resilience framework can be seen in fig.1.

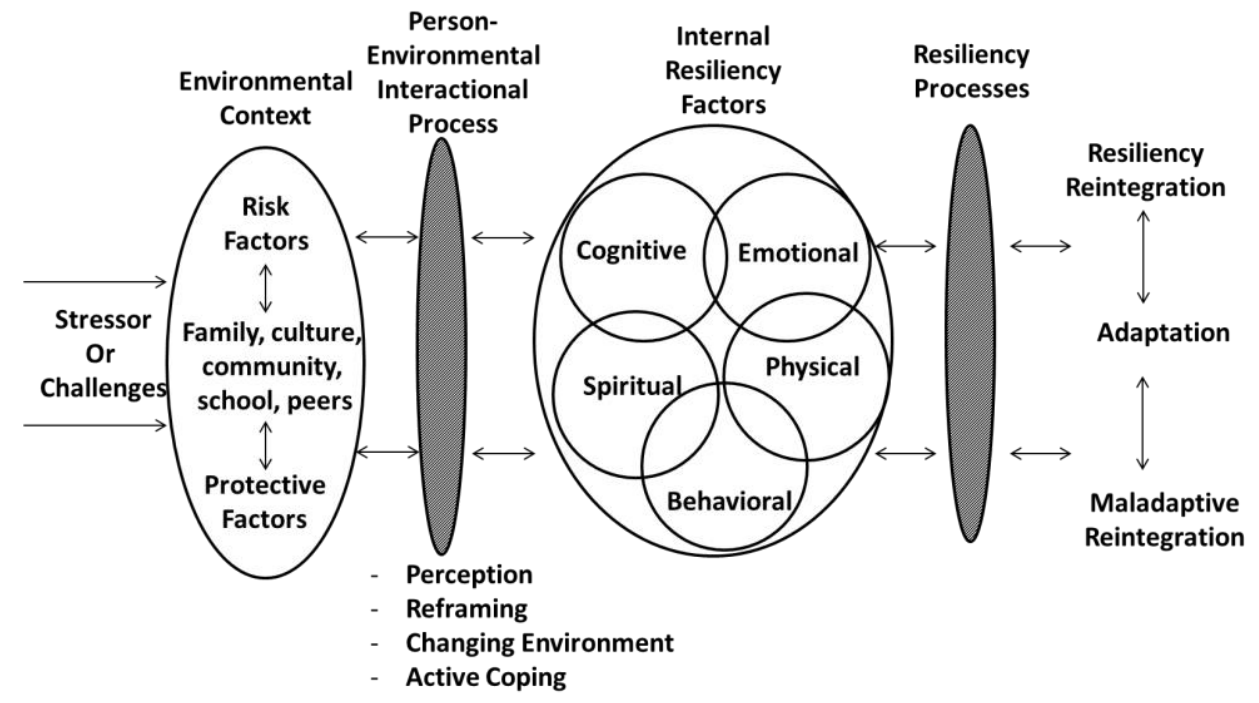

Fig. 1. Resilience Framework consists of six major predictors of resilience (Adapted from "Factors and processes contributing to Resilience: The Resilience framework," by K.L. Kumpfer, 2002 in Longitudinal research in the social and behavioral sciences, An interdisciplinary series: Resilience and development positive life adaptation by M. D. Glantz \& J. L. Johnson. New York: Kluwer Academic Publisher) 
First, the stressor or challenge activates the resilience process and creates an imbalance in the individual. The level of stress perceived by individuals depends on perception, cognitive judgment, and interpretation of the stressor as an unpleasant threat. If an individual is successful in facing the event, the individual will achieve resilience. The presence of challenges or problems helps the individual in facing other stresses and helping the individual to grow. The next factor is the environmental context which the individuals live. This factor is the most influencial factor in attaining resilience. There is a risk and protective factors which can be a challenge or support in resilience process (Kumpfer, 2002). Resilience is built after a complex interaction between risk and protective factors in individual, family, and community levels (Mitchell, 2011). Families, neighbors, schools, and peers are the context where the socialization process takes place. When an acute stressor occurs, the environment can be a buffer for its negative impact. Intra-family support, support of the extended family, support from friends, religion, open communication amongst family members, work, and financial security were factors promoting resilience in divorced families (Greeff \& Van Der Merwe, 2004). Intra-family support refers to support which family members provide to each other. Meanwhile extended family support refers to support obtained from extended kin such as grandfather, grandmother, cousins, aunt, and uncle. Then social support refers to the support from neighbors, schools, and other institutions.

A high-risk environment such as dysfunctional families can be a risk factor in children (Kumpfer, 2002). Snyder and Lopez (2002) describe four protective factors for psycho-social resilience in children and adolescents which include (1) within the child, (2) within the family, (3) within the family or other relationship, and (4) within the community. First, within the child factors are skills which can help individuals in facing the problem. These include of problem-solving skills, positive perceptions, self-efficacy, a positive perspective on life, beliefs and life meaning, good self-regulation of emotional arousal, and good sense of humor. Second, the within family factor includes of having close relationships with adults, supportive families, positive family condition, parental involvement in children's education, and socioeconomic conditions. Meanwhile within family or the other relationship consist of having close relationship to competent, prosocial, and supportive adults, and also having connection to prosocial and peers. Then the within community factors include the school environment, organization, community life, public security, and health services.

The third factor is the person-environmental interactional process. It includes a conscious and unconscious understanding to modify the environment or selectively accept the environmental influences. Liu et al., (2017) revealed that external resilience is closely related to the ecological social context in which resilience developed over time. Some interaction processes that help the youth transform a high-risk environment become more protective environment are: (1) selective perception, (2) cognitive reframing, (3) planning and dreaming, (4) identification and attachment with prosocial people, (5) active environmental modification, and (6) active coping (Kumpfer, 2002). The next factor is self-characteristics. This factor plays a big role in order to achieve successful adaptation in facing the negative stressful events. It consists of (1) spiritual or motivational characteristics, (2) cognitive competencies, (3) behavioral or social competencies, (4) emotional stability and emotional management, and (5) physical well being and physical competencies. These characteristics are needed by the individual to adapt to different task, culture, and environment. The fifth factor is resilience process. This process includes the interaction between individual characteristics and final outcomes. It also includes both short-term and long-term resilience that individuals learn through stressors. The stressors help individuals be able to bounce back. We will not only identify the protective factors in the environment, but also identify the way to create resilience factors by designing and learning the process of achieving resilience. The last factor is a positive outcome or successful adaptation. Positive outcome in specific developmental tasks has a role in achieving positive adaptation in subsequent developmental tasks. It can support in achieving resilience. This outcome is a dynamic model. The current positive outcomes can predict the future outcomes that will be achieved when the individual experiences stress later in life.

Research on parental divorce done by Cui, Fincham, dan Durtschi (2011) found that parental divorce had an impact on the romantic relationship of teenagers and adults whose parents divorced. However, the perceived impact depends on how the subject assesses the divorce of both parents. The perception of young adults about parental divorce depends on the situation of conflict or parental issues before the divorce. Research on resilience in Javanese adolescents done by Ruswahyuningsih and Afiatin (2015) showed that resilience in adolescents was influenced by resilience in Javanese families, by peers' support, and the Javanese cultural values. It includes of rila (willingness), nrima (acceptance), patience, religiosity, and social environment. Teens who experience conflict in the family was found able to get out of the pressure and revive from bad experiences of the past. The resilience includes the ability of teenagers in solving stressful events.

It is fascinating to see how some children achieve resilience, while others do not. In this study, although the subject had experienced parental divorce and family conflict, she did well in her study. Even though she took different majors at two different universities, her Grade Point Average (GPA) were always good. Now, she 
can accept and reconcile with her family problems.

\section{METHOD}

The Phenomenology study describes the essence of individual experience (Creswell \& Creswell, 2007). In this study, Phenomenology was used to understand how the subject interpreted the phenomena occurred in the subjec's life (parental divorce) then reached resilience. The resilience of subject was explored through the resilience framework that consists of six major predictors of resilience: (1) the environmental risk factors, (2) the environmental protective factors, (3) person-environmental interaction processes, (4) the internal selfcharacteristics, (5) the resilience process, and (6) the positive outcome.

Subject in this research is an adult child from a broken home family. Subject was a 25-years-old female graduate student who experienced parental divorce and family conflicts. Data collection techniques used in this study were in-depth- interviews and audio recordings. In-depth-interviews were conducted at the location and time chosen by the subject. The researcher ensured that the location of the interview met the requirements regarding the privacy and confidentiality. Besides the interviews and audio recordings as the main technique, direct observation technique was also used. To improve credibility, qualitative research uses various strategies in ensuring that the issues are not only seen from one lens to get the comprehensively understanding (Baxter \& Jack, 2008). Each data obtained contributes in achieving an understanding of the overall phenomena encountered by the subject of research.

During the first meeting, the subject was asked to fill out the informed consent and be informed of the objectives, risks, and benefits of the research. After signing informed consent, the subject was asked to fill out a demographic form. The interviews were based on questions that have been prepared based on research objectives. After the interview had been completed, the transcript of the interview was made. The researcher then identified the themes that arose from the interview and organized them systematically. Researchers also conducted member checking by sharing the interview transcript to the subject. The subject was requested to review and gave a feedback. If there were an inappropriate transcript or if the transcript did not reflect what the subject submitted during the interview, the subject could make the clarification. Member checking is the source of validity checking in Phenomenology research (Meisenbach, 2010). For a data analysis, Triangulation was employed to ensure that the phenomenon was explored from multiple perspectives. Triangulation of data sources was done by doing an interview with the significant people. The significant people is a friend of subject since in Junior High Scholl who knows the dynamics of the subject's' live. Triangulation also was done by rechecking the subject responses during the interview.

\section{RESULT}

\subsection{The Stressor}

I met Nia, a graduate student from Aceh, in her boarding home located in Yogyakarta. Nia experienced problems related to her family condition that was a broken family. Her mother and father divorced when she started enrolling at a kindergarten in the age of 4 years old in 1995. Nia was the last child in her family, she had two older brothers. When she was a child, Nia experienced family conflict between her biological father and mother. When her parents had a quarrel, she was usually brought into a room by her mother, then her father would bang at the door from the outside. That quarrels had caused fears on her. Nia has a terrible fear of entering a lift or door that she has never encountered before. When entering a new room, she usually checks how the door is opened and closed.

Her mother re-married in 1996, it was when Nia was 5 years old. Her mother then gave birth to two children. Nia's two brothers went to other cities since junior high school while Nia lived with her half siblings. Her mother never explained anything about her divorce to Nia. She also never asked permission from her children when she was about to get married again. Nia understand about her parents' divorce when she was in the third grade of elementary school. Although divorced, Nia's father often visited her at school and brought something that she liked. She asked her father why he did not return home, instead, another man was at home. After understanding her family condition, she felt inferior and uncomfortable when visiting a friend's house and saw her friend's both parents. The genogram of the subject can be seen in Fig. 2 .

Although they have different biological fathers, Nia cares about her half-siblings and try to not make them make them feel different from her. The Nia's mother always says to her that she must care for her step sister and brother. Since childhood, Nia's mother has imparted a value to her children, although they have different fathers, she will treat them in a same way. Anyone who does wrong will be pinched.

In her mother's second marriage, Nia experienced the most traumatic conflict in her life. Her stepfather was a drug and alcohol addict. She often saw quarrels between her stepfather and her mother. At that time, her 
stepfather exploded into anger at home and made her mother's face bruised. Sadly, Nia could not do anything besides pulling her mother's hands. That traumatic incident happened in 2003 when Nia was in junior high school. Nia was terribly sad and angry at that time. However, despite her bruised face, her mother still went to work since she was a secretary of a company. The quarrel had caused fear to Nia when she sees an angry person raising his/her voice. Worse still, it made her develop anxiety regarding her future husband. In 2003, her mother divorced with her second husband.The traumatic conflict which was experienced by Nia was expressed by following quotation.

My emotional problems began to emerge since my mother's second marriage, the divorce was due to domestic violence. I was 13 years old back then, in 2003. I witnessed how they quarrelled; I witnessed my angry step father hit my mom. I was so sad because I was helpless and could do nothing. I remember how my mom could not open her mouth when eating. She was a career woman, she was a secretary and she went to the office with a bruising face.

I couldn't forget it, so if there is a man talking in a loud voice, or a man hitting a girl, I would immediately tremble. My anxiety is regarding whether the man l'm close with will be willing to accept my family, whether he is rude or not.

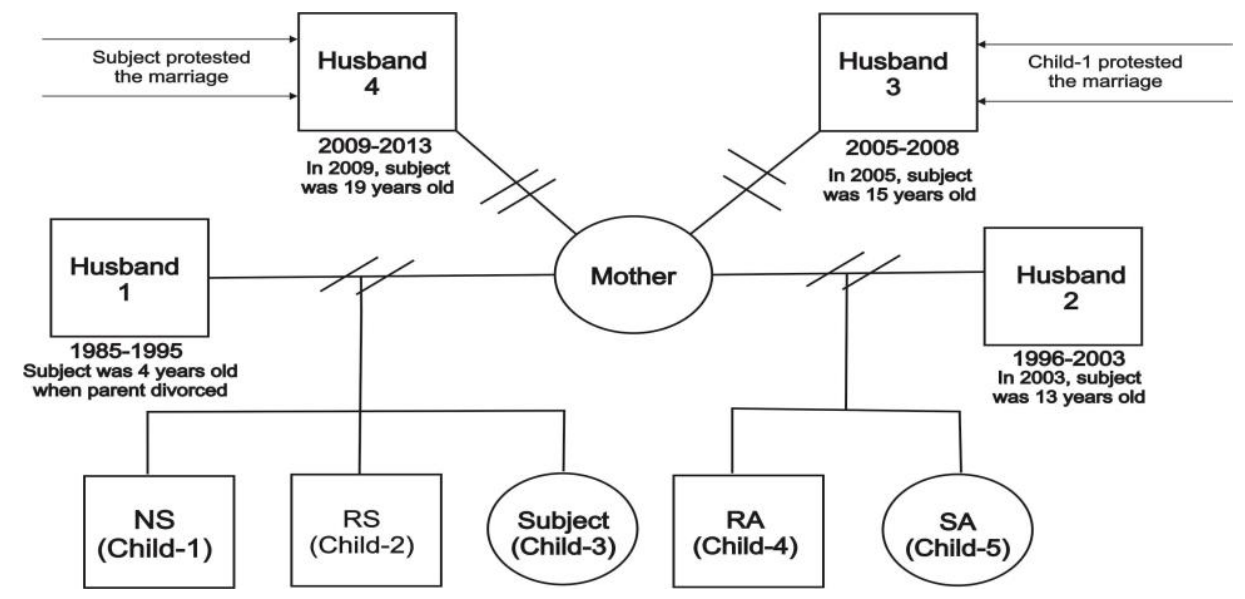

Fig. 2. The Genogram of Subject (Nia's mother married four times and Nia's father was the first husband)

In 2005, her mother got married again. During her mother's third marriage, the subject's brother protested her mother's marriage. It caused a conflict between her brother and mother. Her mother divorced with her third husband in 2008. Nia's communication with her mother was not open at that time. She seemed to position herself in two different roles: as a mother and as a woman. She did not allow her children to interfere or forbid her decision to get married. On the other hand, she also did not allow her husband to interfere in raising their children. Such restrained communication with her mother made Nia avoid sharing her problems with her mother. She explained that at that time, her mother had fluctuating emotions and she could explode into anger.

Family problems that continuously happens, made the subject desperate. When studying in a high school, she had no idea about her future. After her mother divorced with her third husband, the subject began to forbade her mother to remarry. But then in 2009 her mother quietly got married without her knowing. In 2009, $\mathrm{Nia}$ was in college. The unannounced marriage caused depression on her. Nia felt that the God is unfair because she continously experienced the same problem in her life. Then Nia began to rebel against God. She stopped doing obligatory prayers. Until one night, she dreamed of meeting her late grandmother which she considered as a reminder. Since childhood, the subject was taught religion. Her late grandmother played a role in instilling religious values and always suggested the subject to improve her recitation of the Qur'an (the holy Quran of Moslem). She was the grandchild who was taught religious values the most, yet she no longer did it. In fact, her heart became more anxious because she was far from God. Then she realized that she should not turn away from God because the God has done nothing wrong. Her mother divorced with her last husband in 2013.

$\mathrm{Nia}$ also had problems with her friends and boyfriend. Her junior high school friends often mocked and bullied her. Hani, her close friend since the first grade of junior high school, mentioned that Nia did not even want to go to the cafeteria because she was often bullied. During her undergraduate study, Nia took two majors and got a good Grade Point Average (GPA). It made her friends annoyed because they were often compared with Nia. In the boarding house, she also had a problem. Her friend's mother dislike Nia and told her friends to not be a friend with her who came from a broken home. As a result, she had no friends in the 
boarding house. Worse, her boyfriend left her after knowing her family background.

\subsection{Resilience Process}

Resilience process began when Nia realized that there was a problem with her. It happened when Nia was 21 years old and entered her fifth semester in college. After accepting that fact, she decided to undergo a therapy with her lecturer. She previously was not aware of the problems that made her uncomfortable. After several sessions of therapy, she discovered that she had a bad anger management. She was not able to control her anger and did not know how to release it. The root problem of her bad anger management was her emotional repression related to her family's problems. She repressed her anger and her curiosity since childhood. Her emotional problems began when she had a traumatic experience with abusive step father who made her mother's face bruised. Because of her emotional problems, sometimes she exploded her anger to her half-brother who reminded her of her stepfather. After realizing her mistakes, she felt sad and guilty. She was also not open with her mother regarding her sadness of not having any friends and feeling inferior on her family condition. Resilience process can be seen in Fig.3.

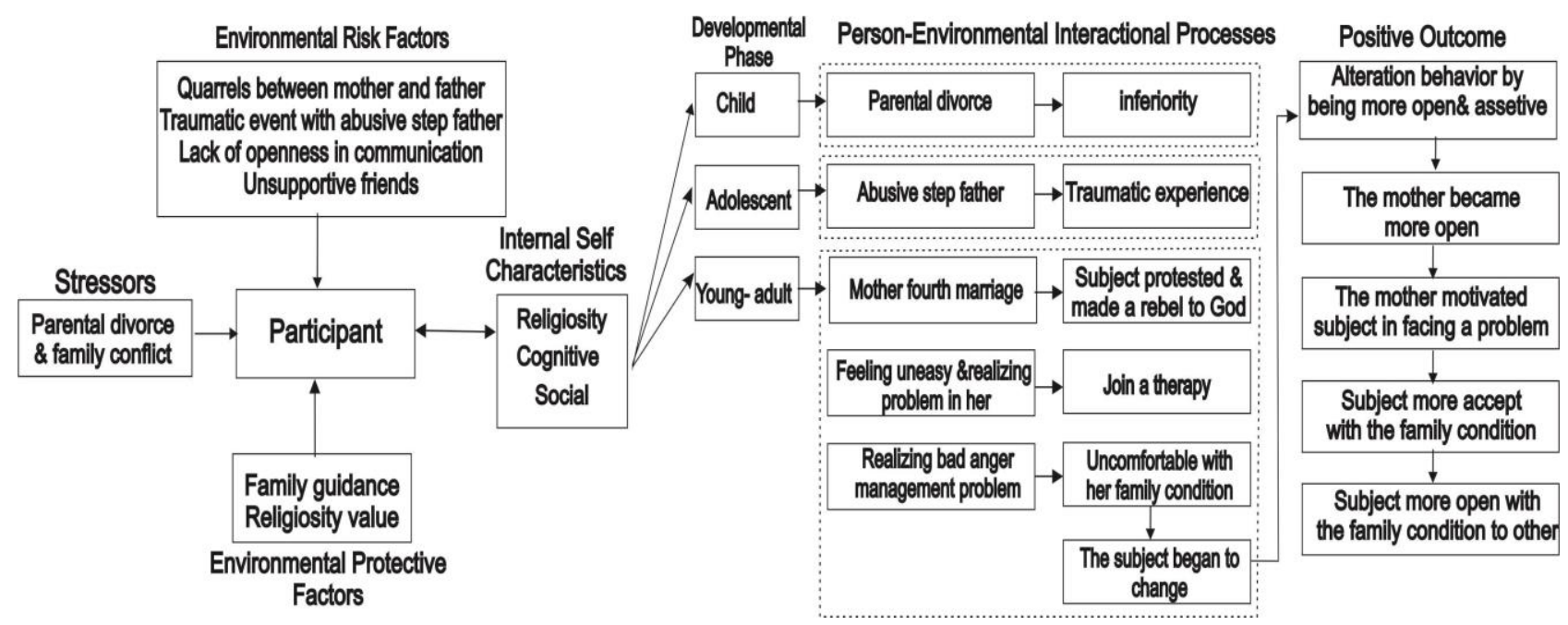

Fig. 3. Resilience Process in the Subject

After realizing the problem, she felt more uncomfortable with her family's condition. She didn't like her mother who appeared to be lonely. Then Nia began to change. Nia, who was previously reticent, sensitive, irritable person, and had a lot of repressed feelings, tried to be more open and assertive. She began to share her problem with her mother. Afterwards, her mother also started to give advice and share her own story related to her divorce with her ex-husbands. The following interview quotes illustrate the resilience process.

Several months after the therapy, the problems were getting clearer bit by bit. Thing seemed to be connecting in my cognition "this is what I repressed yesterday ... this is my problem." It's like finding the problems that made me angry all the time. What made me angry is there were questions that I should have asked, but I did not ask ... there was sadness because I had no friends but I could not tell. I am feeling embarrassed and inferior because of my family conditions, but I could not share it with my mom at that time.

After the therapy, I changed from being a reticent, sensitive, irritable, to be more open person. I am willing to talk about what I think and what I feel. Thus, my thoughts that were previously filled by all repressed feelings started to provide space for me to think about what I want to do, why all this happened in my life, why God chooses me.

My mom started to change and became open because I started to change first. I started to share about my boyfriend. In the fifth semester, I had a thought that I will treat others like how $i$ want to be treat. I try my best not to bother other people. That's what I believe until now. I do not like to be bullied, so I will not bully others. When I saw my mom, I did not like to leave her alone. I do not like being lonely. It was funny when we live in the same house but we did not talk at all, it's weird, so because I did not like that kind of situation, I started to be open.

After attending the therapy, Nia is able to control her emotions by taking a breath or focusing her self on other things. She has swimming as her hobby. This hobby also becomes a way for her to divert her focus and vent her anger. She has a dream to make her mother happy and to take care her younger siblings. Nia wants to be able to redeem her guilt because she used to vent anger to her younger brother. Her mother is 
the main support for her, who always motivates her in dealing the problem, and who suggests her to not be ashamed and not to cover up the condition of their family. The role of her mother in achieving resilience is expressed from the following quotation.

Mamak' said, "Although I am a single parent, my children could be more educated, more polite, more civilized than others. So there's no need to cover it up. "

Mamak is the one who contributes to my stress. But on the other hand, Mamak is a medicine for me, she always cares and strengthens me.

Besides her mother, Nia gets motivation from therapist, lecturer, and her landlord during college. The therapist gives advice and motivation related to Nia's problem. Nia has a good comprehension because she is able to interpret the advice from people around her to motivate herself. Nia also often gets enlightenment from lecturers' advice in class. The landlord often chats and gives wise advice to Nia. Advice and motivation that gives Nia enlightenment can be seen from the following interview quotes.

I remember what the lecturers teach in a class, "You are learning every day in the real world which is free, but each person is given a different exam, the level of the exam is different. The more difficult the challenge you faced, the higher you are. If he or she leveled up, may-be he or she was prepared for a better thing.

The landlord said, "The more stressful your problems, it means God is preparing you for a great thing."

\subsection{Positive Outcome}

The positive outcome from $\mathrm{Nia}$ is that she became more open with her mother. That change make the communication between her mother and her better. Nia's acceptance with her family condition also increased. She understand the problems that she has experienced in the past. Nia realized that everyone has different problems. People can learn something from their problems for their better future. Nia is now more open about her family's condition with her friends. She also can manage her emotion better.

I finally accept ... accepting that this is my family. No matter how bad it is, it is my family. I realized that everyone has different problems. Sometimes we do not know the meaning, lessons, and benefits of an incident. It is not because we are stupid, but because we have not got the understanding. I could only understand all the problems in my past at my current age. Why I was born in such family, experiencing something like this, having those kinds of friends. There must be some lessons from which I can learn.

I think my mother like a wonder-woman, she is incredible. Although she has so many problems, she can strengthen her children, and support her younger siblings.

\section{DISCUSSION}

The major stressors in subject were parental divorce and family conflict. The parents of the subject divorced when the subject was four years old, then subject's mother remarried three times. These stressors made an imbalance in subject. It is consistent with Thomas and Högnäs (2015) that parental divorce experienced before age 7 have an influence in children's health. The parental divorce is positively associated with negative outcomes from early childhood, through adolescence, and into adult. Amato (2014) also said that children with divorced parents experience more mental and physical health problems than the children with married parents. Ermisch and Francesconi (2000) also found that $80 \%$ of stepfamilies are not very stable. Children tend to be worse after a parent's remarriage and the more conflicts there is, the more damaging to children's wellbeing (Mackay, 2005).

In facing the stressors, there were environmental risk and protective factors. The environmental risk factors in this case were open conflict between her mother and father, traumatic experience through witnessing physical abuse of step father, lack of openness in communication with mother, and unsupportive friends. These environmental risk factors became challenges to the subject. It is consistent with Amato and Cheadle (2005) that parents who fight frequently and then divorce increase the risk of problems for their children. The change of family structure impacts the role of family in providing care and chidren's needs and wellbeing (Meçe, 2015). The lackness of openness in communication between subject and mother became a risk factor. The subject repressed the anger, confusion, sadness, as well as problems with friends and boyfriend by herself. These conditions made the subject distress. This is consistent with Linley and Joseph (2004)

\footnotetext{
${ }^{1}$ Mamak means mother, some people in Sumatra usually call mother as mamak.
} 
which reveals that environmental risk factors put the individuals at failure in solving difficult situations. Kumpfer (2002) revealed that high-risk environments, such dysfunctional family create an imbalance in the children.

Although the environments around the subject were high-risk, there is a value that socialized by her mother which guided the subject in facing the problems. Subject's mother loves, cares, and treats her children equally despite their different biological fathers. The subject was also taught to care her sister and brother although their different biological fathers. Beside that, there is religious value which became environment protective factors. The values in her family and religious values taught from childhood serve as a guidance for the subject. This is in line with Kumpfer (2002) conclusion that belief systems help and motivate individual then provide guidance in achieving resilience.

Resilience process began when the subject was already been 21 years old or in the young adult phase. In that age, subject realized that she had a problem. The subject's acceptance with problems made her having an initiative to solve her problems. Then the subject actively coped her problem by joining a therapy. Subject also modified her environment by becoming more open. After knowing that she had a bad anger management related to her emotional repression since childhood, subject began to feel uncomfortable or restless with her family condition and her mother who appeared to be lonely. Then she had an initiative to open up and talk to her mother. It consistent with Kumpfer (2002) that active environmental modification and active coping are interaction processes that help the youth transform a high-risk environment to become more protective environment. Active problem focused coping which was done by subject helped her to solve her problem. Problem-focused coping was a coping strategy which focuses on solving the problem (Lazarus, 1993; Lazarus \& Folkman, 1984). Folkman and Lazarus (1980) revealed that problem-focused coping has a function to change the problem by making a solution and taking action.

Her action in solving problems was supported by subject's internal characteristics. The subject's internal characteristics including religiosity, cognitive, social competencies, and mature age play a role in achieving resilience. Religiosity helped the subject in perceiveng the problems. Belief systems were found positively associated with resilience (Javanmard, 2013). Religiosity is found to be able to provide a source of resilience (Reutter \& Bigatti, 2014; Ruswahyuningsi \& Afiatin, 2015) and is an important strategy in resilience (Reis \& Menezes, 2017). Beside the religiosity, cognitive ability of subject is good. Subject has capability in identifying and realizing her own problem. By understanding the problems, in herself, subject can identity what she must to do in solving her problems. It is consistent with Masten and Coatsworth (1998) that resilience composed of ability to analyze problems. Good cognitive ability of subject made her has a good comprehension in interpreting advices from the people around her to motivate herself. Motivation from the therapist and lecturer gave enlightenment to subject. Grych and Fincham (1990) found that impact of marital conflict is mediated by children's understanding of the conflict, which formed by contextual, cognitive, and developmental factors. Children will be better in facing stressful problem when they are good learners and problem solvers, or they have an area of competence such as in academic (Masten et al., 1990). Beside religiosity and cognitive ability, subject has a good social competency. Her care and empathy to her family made her to change into a better person. It is in line with Masten and Coatsworth (1998) that resilience is composed of empathy. Therefore, subject's internal characteristics play a role in achieving resilience. This is consistent with the findings of Liu et al. (2017) that the resilience focuses on the individual characteristics including psychological resilience, skills, and resources which individuals developed according to their interpersonal experiences. Mature age plays a role in achieving resilience in subject. Subject's understanding of problem was mediated by maturity in age which helped in processing and understanding the problems better. It consistent with Santrock (2002) that adult phase is the time when an individual's reasoning developed and in this phase, an individual being mature in solving problems.

Behaviorally, the subject made a change by being more open and assertive. After that, there was a reciprocity from significant other around the subject. Mother of subject also became more open and motivated her in dealing her problem. Therefore, an open communication was built and subject have social support from her family in dealing problems. It is consistent with Greeff and Van Der Merwe (2004) that open communication between family members and a positive attitude relating to their future as a family were important during their adaptation after the divorce. The family is the basic social unit which plays an important role in care, nurturing, and socialization of children (Meçe, 2015).

The positive outcome is that the subject were more open. That change made the communication between her mother and her better. Subject also become more accepting with her family condition. The positive outcome is a result from interaction of internal characteristics of the subject and the environment. It is consistent with Olson et al. (2015) that resilience is a dynamic process of positive adaptation within the context of significant adversity, trauma, tragedy, threats, or source of stress. 


\section{CONCLUSION}

The finding in this research is consistent with Resilience Framework from Kumpfer (2002) that resilience of a child from broken-home family can be explained by six major predictors of resilience process: (1) stressor or challenge, (2) environmental context, (3) person-environment interactional process, (4) internal selfcharacteristics, (5) resilience processes, and (6) positive outcomes. In addition, there is a new finding that maturity in age and internal characteristics of subject are served as important factors in this case. Maturity in age played a role in processing and understnding the problems better. Therefore, the parental divorce and family conflict as the stressor which experienced by subject since childhood are solved when the subject has already been young adult. The internal characteristics of subject is more dominant in achieving the resilience. The resilience process is triggered by subject's internal characteristics including religiosity, cognitive, and social competencies. These factors appeared and developed as the subject grown up. The process of resilience began with the subject's acceptance and active coping in facing the problems. The openness in communication which get reciprocity from the significant other around the subject by giving social support to subject has a role in achieving resilience. Therefore, the lesson learned from this case are resilience can be achieved if the individual who exposured the stressors coped the problem actively. It is supported by both of internal and external resilience factors which include of: (1) acceptance, (2) religiosity, (3) cognitive ability, (4) social competencies, and (5) social support. Mature age seemed to be an important factor in achieving resilience since it reflect maturity in those factors cited previously.

\section{ACKNOWLEDGEMENT}

This research financially supported by LPDP (Indonesian Scholarship). My sincere thanks to my subject involved in this research who allowed me to come to their experiences. I wish to thank Professor Tina Afiatin and Dr. Budi Andayani, M.A (Department of Psychology, Universitas Gadjah Mada) for reviewing this article.

\section{REFERENCE LIST}

Amato, P. R., \& Keith, B. (1991). Parental divorce and the well-being of children: A meta-analysis. Psychological Bulletin, Vol. 110, No. 1, 26-46.

Amato, P. R. (2014). The consequences of divorce for adults and children: An update. Drustvena Istrazivanja, 23(1), 5-24. https://doi.org/10.5559/di.23.1.01

Amato, P. R., \& Cheadle, J. (2005). The long reach of divorce: Divorce and child well-being across three generations. Journal of Marriage and Family, 67(1), 191-206. https://doi.org/10.1111/j.00222445.2005.00014.x

Baxter, P., \& Jack, S. (2008). Qualitative case study methodology: Study design and implementation for novice researchers. The Qualitative Report, 13(4), 544-559.

Chen, J.-D. (2005). Cultivating resilience in children from divorced families. The Family Journal, 13(4), 452455. https://doi.org/10.1177/1066480705278686

Creswell, J. W., \& Creswell, J. W. (2007). Qualitative inquiry \& research design: choosing among five approaches (2nd ed). Thousand Oaks: Sage Publications.

Cui, M., Fincham, F. D., \& Durtschi, J. A. (2011). The effect of parental divorce on young adults' romantic relationship dissolution: What makes a difference? Personal Relationships, 18(3), 410-426. https://doi.org/10.1111/j.1475-6811.2010.01306.x

Ermisch, J., \& Francesconi, M. (2000). The increasing complexity of family relationships: Lifetime experience of lone motherhood and stepfamilies in Great Britain. European Journal of Population/Revue Européenne de Démographie, 16(3), 235-249.

Folkman, S., \& Lazarus, R. S. (1980). An analysis of Coping in a middle-aged community sample. Journal of Health and Social Behavior, 21(3), 219. https://doi.org/10.2307/2136617

Greeff, A. P., \& Van Der Merwe, S. (2004). Variables associated with resilience in divorced families. Social 
Indicators Research, 68(1), 59-75.

Grych, J. H., \& Fincham, F. D. (1990). Marital conflict and children's adjustment: A cognitive-contextual framework. Psychological Bulletin, Vol 108. No 2, 267-290

Javanmard, G. H. (2013). Religious Beliefs and Resilience in Academic Students. Procedia - Social and Behavioral Sciences, 84, 744-748. https://doi.org/10.1016/j.sbspro.2013.06.638

Kelly, J. B., \& Emery, R. E. (2003). Children's adjustment following divorce: Risk and resilience perspectives. Family Relations, 52(4), 352-362.

Kumpfer, K. L. (2002). Factors and processes contributing to Resilience: The Resilience framework. In Glantz, M. D., \& Johnson, J. L. Longitudinal research in the social and behavioral sciences, An interdisciplinary series: Resilience and development positive life adaptation. New York: Kluwer Academic Publisher.

Lazarus, R. S. (1993). Coping theory and research: past, present, and future. Psychosomatic Medicine, 55(3), 234-247.

Lazarus, R. S., \& Folkman, S. (1984). Stress, appraisal, and coping (11. [print.]). New York: Springer.

Linley, P. A., \& Joseph, S. (Eds.). (2004). Positive psychology in practice. Hoboken, N.J: Wiley.

Liu, J. J. W., Reed, M., \& Girard, T. A. (2017). Advancing resilience: An integrative, multi-system model of resilience. Personality and Individual Differences, 111, 111-118. https://doi.org/10.1016/j.paid.2017.02.007

Mackay, R. (2005). The impact of family structure and family change on child outcomes: A personal reading of the research literature. Social Policy Journal of New Zealand, 24(4), 111-133.

Masten, A. S. (2001). Ordinary magic: Resilience processes in development. American Psychologist, 56(3), 227-238. https://doi.org/10.1037//0003-066X.56.3.227

Masten, A. S., Best, K. M., \& Garmezy, N. (1990). Resilience and development: Contributions from the study of children who overcome adversity. Development and Psychopathology, 2(4), 425. https://doi.org/10.1017/S0954579400005812

Masten, A. S., \& Coatsworth, J. D. (1998). The development of competMeçe, M. (2015). Impact of Family Structure Changes on Child Wellbeing. Balkan Social Science Review, 6, 109-137.

Meçe, M. (2015). Impact of family structure changes on child wellbeing. Balkan Social Science Review, 6, 109-137.

Meisenbach, R. J. (2010). The female breadwinner: Phenomenological experience and gendered Identity in Work/Family Spaces. Sex Roles, 62(1-2), 2-19. https://doi.org/10.1007/s11199-009-9714-5

Mitchell, F. (2011). Resilience: Concept, factors and models for practice. Stirling, Scotland: Scottish Child Care and Protection Network.(No. None). Retrieved from

http://www.kelsi.org.uk/_data/assets/pdf_file/0018/35460/20th-May-15-KS-resilience-concept-factorsand-models-for-practice.pdf

Olsson, L., Jerneck, A., Thoren, H., Persson, J., \& O'Byrne, D. (2015). Why resilience is unappealing to social science: Theoretical and empirical investigations of the scientific use of resilience. Science Advances, 1(4), e1400217-e1400217. https://doi.org/10.1126/sciadv.1400217

Reis, L. A. dos, \& Menezes, T. M. de O. (2017). Religiosity and spirituality as resilience strategies among long-living older adults in their daily lives. Revista Brasileira de Enfermagem, 70(4), 761-766. https://doi.org/10.1590/0034-7167-2016-0630

Reutter, K. K., \& Bigatti, S. M. (2014). Religiosity and spirituality as resiliency resources: Moderation, mediation, or moderated mediation? Journal for the Scientific Study of Religion, 53(1), 56-72.

Rodgers, K. B., \& Rose, H. A. (2002). Risk and resiliency factors among adolescents who experience marital transitions. Journal of Marriage and Family, 64(4), 1024-1037.

Ruswahyuningsi, M. C., \& Afiatin, T. (2015). Resiliensi pada Remaja Jawa. Gadjah Mada Journal of Psychology, 1(2). Retrieved from https://journal.ugm.ac.id/gamajop/article/view/7347

Santrock, J. W. (2002). Life-Span Development Sixth Edition Chapter II. Jakarta: Erlangga 
IJASOS- International E-Journal of Advances in Social Sciences, Vol. III, Issue 9, December 2017

Snyder, C. R., \& Lopez, S. J. (Eds.). (2002). Handbook of positive psychology. Oxford [England] ; New York: Oxford University Press.

Thomas, J., \& Högnäs, R. S. (2015). The effect of parental divorce on the health of adult children. Longitudinal and Life Course Studies, 6(3). https://doi.org/10.14301/llcs.v6i3.267

Whitton, S. W., Rhoades, G. K., Stanley, S. M., \& Markman, H. J. (2008). Effects of parental divorce on marital commitment and confidence. Journal of Family Psychology, 22(5), 789-793.

https://doi.org/10.1037/a0012800 